\title{
Poetics of the Shipping Forecast
}

\author{
Sanna Nyqvist
}

\begin{abstract}
This essay investigates the intertextual manifestations of radio shipping forecasts in fiction, poetry and non-fiction from the United Kingdom, Ireland, Sweden and Finland. The literary adaptations and appropriations of the functional meteorological report often retain its peculiar melodic character that results from the compressed, elliptic listing of observations or warnings. In the listening experience evoked by many authors the relative safety of the radio listener's everyday surroundings contrasts with the threat of gales and harsh conditions for seafarers. A comparative analysis shows that despite the insularity of the shipping forecast as a cultural phenomenon, the "literature of the shipping forecast" is surprisingly similar in different countries, exploring the same themes of nostalgia, loss of signification and definition of borders. The essay also investigates how the shipping forecast inevitably evokes questions of territorial conquest and exclusion of others, and how its literary adaptations tend to bracket the natural phenomena that are the very raison d'etre of the shipping forecast.
\end{abstract}

The shipping forecast is a curious radio broadcast. Issuing gale warnings for seafarers and communicating weather information from coastal stations, it is reminiscent of a time when reliable and up-to-date weather reports were available only through radio. Nowadays, professional mariners as well as pleasure boaters get the necessary weather information through modern wireless technologies, and the shipping forecast has become a relic in the radio's programme schedule. Most of the avid listeners to the radio's shipping forecast do not need the information it conveys: they are safely situated inland, far away from the rough seas and gushing winds. The continuing appeal of the radio programme does not reside in its practical usefulness, but in other qualities, which I will call here "the poetics of the shipping forecast". I mean poetics in two senses. Detached from its practical objective, the shipping forecast becomes everyday poetry, appreciated for its aesthetic qualities that include repetitive rhythm, elliptical expression, evocative place-names, and meteorological jargon. These qualities have in turn been appropriated by poets and authors of fiction who 
have incorporated the familiar, iconic discourse of the shipping forecast into their work.

In this essay, I will explore the affective and geopolitical aspects of the shipping forecast through its uses in poetry, fiction and non-fiction. The shipping forecast is a spatial narrative mapping the maritime borders of seafaring nations, but in its cultural uses as everyday poetry or appropriated discourse in literature, it does not primarily refer to actual geographical places, but evokes inner landscapes, often transporting the experiencer to another place and time. Typically, the soothing litany of coastal stations evokes memories of childhood, viewed from a nostalgic perspective. The affective response to the shipping forecast builds on the simultaneous presence of danger and safety: the immanent perils in the constantly changing weather conditions at sea highlight the comfort of the listener's domestic setting. The longevity of the radio's shipping forecast and the shared mode of its reception have made it a part of the national heritage, a status that is problematic given the international focus of commercial navigation and the inclusion of weather information from areas beyond the borders of territorial waters. The question is whether the shipping forecast feeds a sense of belonging that separates "us" from "others" or whether it has the power to alert us to the transnational aspects of seafaring and the multiculturality of the many archipelagic regions that feature in it.

The shipping forecast thus calls for a geocritical interpretation that traces the affective, cultural and geopolitical aspects of this particular discourse that focuses on distant sea areas. One could argue that time is likewise a constitutive element of the shipping forecast, as it is broadcast at certain hours several times a day, and as the weather information is constantly changing. However, it is the fixedness of the geographical places or area codes that have given the shipping forecast its iconic cultural status and that casts it as a predominantly spatial discourse. Yet, few of its landbound listeners could with accuracy identify these places on a map. It is perhaps just the remoteness of the areas of the shipping forecast that gives free rein to imagination and allows the listeners to use the shipping forecast to map their own inner landscapes.

Many of the weather stations are located on remote islands, which have a particular appeal for the imagination, as the author of Atlas of Remote Islands, Judith Schalansky (2010, p.20), has pointed out: "An island offers a stage: everything that happens on it is practically forced to turn into a story, into a chamber piece in the middle of nowhere, into the stuff of literature." In her analysis of Schalansky's Atlas, Anne B. Wallen (2014) notes that in fiction the science of cartography can be turned into a vehicle of personal investigation and reflection. The shipping forecast is perhaps an extreme example of the use of cartographic data for introspection: passing hastily by a number of 
places in opposite directions, it has not the power to evoke a sense of presence of the places mentioned in it, but instead it summons the listener to follow his or her own associations with other places, places of memory. The scientific and geographical accuracy of the shipping forecast does not feed a mimetic impulse, but rather invites imaginary travels - hence also the disappointment of some readers when encountering books that pictorially represent the places mentioned in the shipping forecast, as the pictorial realism interferes with their freedom not to locate the places of the shipping forecast on any actual map or geographical reality. The shipping forecast is thus a paradoxical form of spatial discourse that rather draws the experiencers away from the places it evokes.

In addition to being a specific form of spatial discourse, the shipping forecast also represents a rather rare instance of intermediality where a radio programme has been integrated into other art forms. ${ }^{1}$ The instantly recognizable form and vocabulary of the shipping forecast make it easily quotable material and its cultural significance means that it can be borrowed or varied in different contexts and to different ends. Yet, as I will suggest towards the end of this essay, there are aspects of the shipping forecast which have not been fully realized in adaptations and which leave new territories open for literary exploration.

\section{Science, Poetry, Magic}

The shipping forecast is a beloved national institution in many seafaring countries. The British Broadcasting Company (ввС) and the Finnish broadcasting company, Yleisradio, have been airing it since the 1920s, and the Swedish national variant was separated from the weather forecast, giving it its own programme, in $1939 .{ }^{2}$ My essay explores the cultural influence of these three versions, although I have no doubt that other countries with

1 In addition to literature, the shipping forecast has featured in music, stand-up comedy and TV shows.

2 The Swedish Sjörapporten airs on Radio P1, the Finnish Merisää on Radio Suomi and its Finland-Swedish sibling Sjöväder on Radio Vega. In this essay, I will use the name of the British programme (on в вС4), Shipping forecast, as the generic term for forecasts of maritime weather. For the histories of the national shipping forecast broadcasts, see e.g. Compton, 2016, pp.7-28; Connelly, 2004, pp.19-34; Jefferson, 2011; Nilsson \& Nylund, 2012. The literature inspired by the British shipping forecast has been analyzed previously by Brannigan (2010) and Carolan (2011), but my article is, to my knowledge, the first to offer a comparative perspective. 
similar shipping-forecast traditions could provide equally insightful examples of the cultural and literary appropriations of maritime meteorological discourse.

Today, the radio programme is accompanied with web services and technologies which have in many cases made it obsolete, but the radio broadcast has nevertheless retained its prominent place in the daily schedule of the national radios. The longevity of the broadcast has contributed to its popularity: few radio programmes are familiar to listeners of different generations in the way the shipping forecast is. All three national variants are equally beloved in their countries, but they differ somewhat in presentation and context, which is also reflected in their connotations and literary uses. The iconic daily airing of the в вС shipping forecast at 00.48 a.m. begins with a light piece of music, "Sailing By" by Ronald Binge, to help the long-wave listeners to tune in before the potentially vital weather information. The strictly coded threeminute, 370-word programme ends with the national anthem, "God Save the Queen", which also marks the ending of the day's radio broadcasts. On Swedish radio, the twelve o'clock noon broadcast of the sjörapporten (literally "sea report") is followed by an equally cherished daily ritual: the poem of the day. The succession of the programmes enhances the poetic qualities of the former, and enables an unchanging listening experience for the majority of listeners who are not primarily interested in the information conveyed in the sjörapporten.

The core of the Finnish and Swedish shipping forecasts is the weather report from the measuring stations located on distant peninsulas or islands in the outer archipelago. The report includes the latest information on local weather conditions, such as the temperature, visibility and wind speed from forty-two (Swedish) or thirty-eight (Finnish) coastal stations. The charm of the weather report lies in the constant, familiar litany of the names of the weather stations which create a geographical point-to-point map charting the boundaries of territorial waters. The evocative place-names of distant weather stations have become part of the cultural heritage to the extent that people are resistant to changes in the programme. The Finnish weather station located on the island of Kuuskajaskari ${ }^{3}$ was closed in 1999 and consequently removed from the shipping forecast. However, most adult Finns would still mention Kuuskajaskari as the archetypal odd name that features in the broadcast - it even makes an appearance in Marika Maijala and Juha Virta's

3 The compound name is unusual in that even native Finnish speakers have trouble identifying its components (Kuus-kajas-kari or Kuuska-jaskari). 
children's book Sylvi Kepposen hukkaretki ("Sylvi Kepponen's Wolf Hunt") published in 2010, where a little girl is listening to the shipping forecast in the cosy setting of her grandfather's kitchen. ${ }^{4}$ Similarly, Heligoland still exists in the British imagination although it has been replaced by German Bight in the в ВС shipping forecast.

The ввс shipping forecast also includes weather information from coastal stations, but its most beloved element is the 370-word (or 350-word in the daytime broadcasts) prognosis for thirty-one sea areas famous for their peculiar area codes, such as Dogger, Rockall, Viking, or Fitzroy. The areas are not listed in a fixed order but in the order of similarities in weather conditions, which produces new code combinations in each broadcast, giving variability to the otherwise strictly uniform message. The list format and four broadcasts a day make repetition into one of the characteristic elements of the shipping forecast. Although the weather conditions are never the same, most listeners experience the shipping forecast as an unchanging litany.

In addition to repetition and coded expressions, the most prominent poetic feature of the shipping forecast is radical ellipsis: words such as "windspeed" or "visibility" are almost completely omitted, making it difficult to distinguish between items belonging to different categories. For instance, the forecast for South Utsire (one of the areas in the ввС shipping forecast) from February 4 , 2019, is probably incomprehensible for someone not familiar with the elliptic structure of the message: "South Utsire: Southerly becoming cyclonic, 5 to 7 , perhaps gale 8 later. Moderate or rough. Rain, then showers. Good, occasionally poor." 5 For those listeners who do not need the weather information, the forecast appears as a sort of nonsense poetry, where the auditory qualities of the text become far more important than its meaning. Through its ritualistic presentation on the national radio, the shipping forecast has become a part of the collective experience to the extent that it has become a secular prayer, a familiar chant sheltering its listeners from storms and perils. Like common prayers, the shipping forecast draws its power from its apparent constancy and from the collective experience. In the cultural reception of the shipping forecast, the scientific prognoses for windspeed and visibility turn into everyday magic.

4 What enhances the fictionality (as opposed to the factual content) of the represented shipping forecast is the temperature reading given for Kuuskajaskari, 1 degree Celcius, an absurd figure for the warm summer months depicted in Maijala and Virta's book.

5 The message decoded: "South Utsire: WIND: Southerly becoming cyclonic, 5 to 7 BEAUFORTS, perhaps gale 8 BEAUFORTS later. SEA STATE: Moderate or rough. WEATHER: Rain, then showers. VISIBILITY: Good, occasionally poor." (Met Office, online). 


\section{Nostalgia}

In the popular imagination, the most common emotive and cognitive elements associated with the shipping forecast are childhood memories. Depictions of the suggestive power of the experience of listening to the maritime weather are omnipresent in the literature of the shipping forecast. Charlie Connelly (2004, p.2), author of the travel book Attention all Shipping: AJourney Round the Shipping Forecast describes how the legendary opening words "And now the shipping forecast issued by the Met office" evoke the safe and homely setting of the kitchen in his childhood home, where the 6 o'clock shipping forecast marked the time for his evening tea. L.-G. Nilsson and Anders Nylund (2012, p.8) likewise begin their history of the Swedish sjörapporten with a childhood memory, where a child playing under the kitchen table in his grandparent's house becomes alerted to the exotic names of the weather stations which evoke in his mind fanciful images and associations. The memory is narrated in a way that makes it impossible to tell whether it belongs to Nilsson or Nylund or whether it is a fictionalized account of an experience common to generations of listeners. The memory is almost identical to that of Anne-Maria Körling (2014), a Swedish writer and educator, who likewise connects the shipping forecast with staying in her grandparents' house as a child and listening to the radio from a safe hiding-place, a bed in the adjacent room. The strange names of lighthouses and observation points evoke stories in the child's mind. The memories conjured up by the shipping forecast tap into a more general nostalgia for the lost age of innocence, when children understood things differently from adults and were sheltered from the bare and crude facts of everyday life.

This aspect of the shipping forecast is taken up by the Finnish author Petri Tamminen in his 2002 collection of short stories, Piiloutujan maa (Hiding Places, 2007), a slyly philosophical book that consists of descriptions and recommendations of hiding places for adults. One of the hiding places is found in the middle section of a half-empty local bus in the countryside: "Mielen valtaa miellyttävä unohdetuksi tulon tunne. Etupaneelin kello on seisahtunut kahteentoista ja radiosta kuuluu merisää." (Tamminen, 2002, p.89) ["Your mind is overcome by the pleasant feeling of being forgotten. The clock on the front panel has stopped at twelve o'clock and from the radio comes the marine weather report." (Tamminen, 2007, p.78)]. The white noise of the shipping forecast seems to wipe out even the subject himself: he disappears not only from the constraints of ordinary life but also from himself, the constantly observant ego. The bus is on its way to somewhere and the weather report apparently progresses in time and space, but the clock stands still, allowing the subject to disappear in the comfortable bus seat like in a pocket of time. When 
the bus reaches its destination, the hider is filled with a sense of overflowing happiness and recovery.

This kind of (childhood) nostalgia associated with the shipping forecast is uncomplicated, comforting and escapist. It lacks the painful element of homecoming, a realisation of the irreversibility of time and change, which is central to Julia Dahlberg's Islossning ("The Breaking of the Ice", 2011), a coming-of-age novel of a young woman, Sofia, born and raised on the fictional island of Ängö in the Borga (Porvoo) archipelago in the Gulf of Finland. The shipping forecast functions as a prelude to the unexpected friendship, and later love story, between Sofia and her old neighbour, William, both outsiders in the closed island community. When they meet for the first time, 16-year-old Sofia has brought William a loaf of bread baked by her mother and stays in his kitchen for afternoon tea. The radio is on and the presenter is reading the weather report from coastal stations. It provides a sense of security to this loaded and somewhat awkward first meeting between the protagonists of the novel.

Dahlberg quotes from the shipping forecast again at the very end of the novel. Sofia's narrator's voice fades off with the weather report describing the conditions of early spring, the time of the breaking of the ice, a powerful symbol for change, freedom and new beginnings. Sofia, who was forced to leave Ängö and her beloved William, has returned, this time for good. She is again in the kitchen of the cottage, which William has left her in his will, and switches on William's old radio. The shipping forecast functions as a frame for the story of their unusual relationship, providing a kind of closure to the otherwise elliptical narrative. In Dahlberg's novel the scientific accuracy of the measured weather conditions - "Makilo + 16, västsydväst tre, halvklart, god sikt", ["Mäkiluoto +16 , east-southeast three, partly cloudy, good visibility"] - contrasts with the inaccuracy of memory and the inevitable unreliableness of storytelling (Dahlberg, 2011, p.116). ${ }^{6}$ Yet, by including in the report the standard phrase on missing information - "Uppgifter för Jussarö saknas" ["Information from Jussarö missing"] (2011, p.116) - , Dahlberg hints at a deficiency in the scientific discourse: there are lacunae when a message from a weather station has not been able to reach the meteorological offices on the mainland.

Like Dahlberg, the Scottish poet Carol Ann Duffy has used the shipping forecast as an evocative "background noise" in her sonnet "Prayer" from Mean Time (1993). The final couplet of the poem fades off with the area names from the ввС shipping forecast: “Darkness outside. Inside, the radio's prayer - /Rockall. Dogger. Malin. Finisterre" (Duffy, 1993, p.52). Duffy's subjects live in a world

6 Translations of Dahlberg are the author's. 
where "we cannot pray" or "we are faithless". Yet, prayers manifest themselves in the noises of everyday life, such as the "Latin chanting of a train", "Grade I piano scales" or the litany of area names in the shipping forecast. As John Brannigan (2010, p.6) has pointed out, the areas mentioned in the poem are all remote and constitute an unusual combination which can be interpreted as forming the sign of the holy cross. Through their nostalgic associations, the comforting sounds from childhood - piano scales, Latin prayers and the shipping forecast - provide a sense of redemption and hope that contrasts with the "darkness outside."

\section{Loss of Meaning}

While the loss of meaning produced by the extremely elliptical and repetitive nature of the shipping forecast can have a soothing or even sedative effect, it may also conjure a sense of existential loss. In her novel Purkaus (2014, "Eruption"), the Finnish author Anna-Kaari Hakkarainen describes the familiar experience of listening to the shipping forecast in order to throw into relief the tragic situation of her protagonist, Kjarri. Alienated from Birk - his brother, childhood friend and a rival in love - , Kjarri has stayed behind on their home island. Listening to the shipping forecast, the names of the weather stations pass through him, divested of their meaning because they are too familiar to him (Hakkarainen, 2014, p.81). This is what happens to some lovers, Kjarri ponders, who after many years suddenly realize that they no longer understand why the other one is there and who he or she is. The meaningless poetry of the shipping forecast functions as a symbol for the disorientation and sense of loss experienced by Kjarri following his alienation from Birk and after his marriage to the girl they both loved has become stale. The unexpected mention of Birk's name in the broadcast following the shipping forecast suddenly restores the meaning of words and underlines the still acute connection between the brothers. Although Hakkarainen's novel is set in the Westman Islands on the coast of Iceland, the key shipping forecast scene speaks to her Finnish audience, familiar with the litany of coastal stations in merisää.

The repetitiveness of the shipping forecast also functions as a complex symbol for married life in the British poet Seán Street's poem "Shipping Forecast: The Fisherman and His Wife in Donegal" from Radio and Other Poems (1999). The elderly pair, listening to the "weather's unlistening geography" (Street, 1999, p.17), no longer need any words between them. The word "routine" gets repeated three times towards the end of the poem, but here, unlike in Hakkarainen's novel, routine does not necessarily signal alienation, but 
continuity and absence of change which, for an old couple, might be just what they wish for.

Contrary to the more common reception of the shipping forecast as nonsense poetry, Seamus Heaney in his "Glanmore Sonnet VII" uses the list of area codes to symbolize the evocative power of language. The poem is structured around four lists. The first and last are excerpted from the shipping forecast, while the second is a playful burst of ancient, near-identical terms for roads or routes ("eel-road, seal-road, keel-road, whale-road"), and the third consists of a list of names of French vessels taking shelter in Wicklow Bay. The rhythm created by these lists represents the alternating balance between surges of gale winds and calm weather. The last sestet of the poem describes the speaker's epiphany, looking at the vessels sheltering from storm:

\section{L'Etoile, Le Guillemot, La Belle Hélène}

Nursed their bright names this morning in the bay

That toiled like mortar. It was marvellous

And actual, I said out loud, 'A haven,'

The word deepening, clearing, like the sky

Elsewhere on Minches, Cromarty, The Faroes.

HEANEY, 1998, p.162

The poem ends with the calming effect familiar from many other renderings of the shipping forecast, but here the effect is combined with a newly found pleasure and certainty of naming. The names of areas from the forecast function here as means of whetting the appetite for the combined magic of sound and signification in language. The speaker says aloud, "A haven," and the echo of the word clears the skies.

\section{Borderlining}

Experienced as nonsense poetry or a string of evocative phrases, the shipping forecast nevertheless has strong nationalistic undertones. It is a version of cartography where the borders of a state are extended far beyond the limit of its territorial waters. The British shipping forecast covers a vast area from Gibraltar to the coast of Iceland, attesting to the past of the nation as a seafaring empire. The iconic daily airing of the ввС shipping forecast at oo.48 a.m. ends with the national anthem, "God Save the Queen", which not only enhances the prayer aspect of the forecast, but also ties it to the strongest possible nationalistic discourse. Victoria Carolan (2011, pp.105-106) has pointed out how the attitude 
towards the British shipping forecast has changed from the 199os onwards: the weather report has become a part of a political and nationalistic dialogue. The change of the name of the southwestern shipping forecast area from Finisterre to Fitzroy in 2002, to avoid conflict with the Spanish maritime weather maps that used the name Finisterre for a slightly different area, was cast in the British press as a "war" with Spain and an infringement of the territorial rights of the UK by the European Union, although the renaming was initiated by the United Nations World Meteorological Organisation, not by the EU.

Thus, the shipping forecast represents a form of territorial conquest, albeit in the name of safety. In some cases, the territorial claims do extend from meteorological maps to real life. Rockall, a tiny and almost inaccessible cliff in the Atlantic, northeast of the Irish coast, that gave its name to one of the areas in the ввС shipping forecast, has for decades been the centre-point of territorial claims from four nations (UK, Ireland, Iceland, Denmark) due to the potential oil and fishing rights in that area.

David Chandler, in his preface to Mark Power's book on the ввС shipping forecast, writes that the forecast "appeals to an idea of geographic space free from current political conflict, complexity and social tensions" (quoted in Brannigan, 2010, p.9). This is the escapist view of the shipping forecast, extended from the nostalgic, private childhood memories to the level of geopolitics. But whenever the wider implications of the shipping forecast are considered, it is impossible to avoid just these complexities. In "Shore Lines", a long poem by the British author Andrew Waterman (first published in The End of the Pier Show, 1995), the litany of the ввС shipping forecast is interwoven with the poet's experience of blindness after an eye operation and the dramatic onset of the Gulf War in 199o. At night-time, the poet lies in bed, tuning in "to the Shipping Forecast's poetry":

Then follow the reports from coastal stations, Boomer ... Dover ... Mumbles ... My imagination's

Jumped point-to-point round bays and promontories Of our whole shore-line, varying sweeps of sand, Castle-topped headlands harbouring ancient stories ... WATERMAN, 200o, p.26o

This is a more unusual rendering of the $\mathrm{BвC}$ shipping forecast as it mixes the reports from coastal stations (Boomer > Boulmer) with the areas that appear in the forecast proper (Dover) and the nonsense into which the names merge in the listener's ear (Mumbles). Disregarding the mix of names, the shipping 
forecast nevertheless allows the poet to sketch in his mind the borders of the British Isles. John Brannigan (2010, p.8) has interpreted the shifting uses of the pronoun "our" in the poem as symbolising a "revisioning" of the fragmented British Isles in a way that makes the shore-line a symbol not of defensiveness and insularity, but of connection. Yet, the question remains, how extensive is this connection? Later in the poem, the area codes evoke a metaphor that clearly distinguishes between "my native land" and what lies beyond:

\author{
Fastnet ... Humber ... Thames ... Wight ... Finisterre ... \\ Disease and disability are like \\ I've heard, a foreign country. Exiled there, \\ I whisper to a cassette recorder mike \\ Memories of my native land that spike \\ All new resolve: landscapes I used to know. \\ WATERMAN, 200o, p.261
}

The noncommittal "I've heard" does not restrain the poet from affirming the association between disease and foreign territory, ominously preceded by one of the remote shipping forecast areas that are named after foreign places (Cape Finisterre in Galicia) and that lie beyond the territorial waters of the UK and Ireland. At the end of the poem, his sight restored, he revisits Cromer, mentioned in the shipping forecast, asserting his re-entry to the "native land" of the healthy. Thus, while imagining a more connected and less conflict-ridden British Isles that resonates with the recovery of his sight and health, Waterman builds a border against what lies beyond his island community: darkness and disease.

Trying to define what the borderline mapped in the shipping forecast means often produces uncomfortable answers. In a 2007 interview, Mark Damazer, the former ввс Radio 4 controller, crystallized the nationalistic take on the shipping forecast as follows: "It scans poetically. It's got a rhythm of its own. It's eccentric, it's unique, it's English." (Young, 2007) The ввС announcer Chris Aldrige likewise sees the shipping forecast as "something that defines us as an island nation" (Compton, 2016, p.3), and his colleague Zeb Soanes describes the radio programme as being a "part of the fabric of this intangible thing called Britishness" (Compton, 2016, p.4). Carolan, who has analyzed the political and cultural aspects of the ВвС shipping forecast equally argues that "there is no evidence to suggest that any other country has a similar reaction to its forecast" (Carolan, 2011, p.110).

While the British arguably foster a particularly strong affection for their shipping forecast, my comparative analysis shows that a similar weather report 
in other countries likewise figures in the popular imagination. The similarities in the national reactions to the shipping forecast even include the notion that each nation thinks of its shipping forecast as a unique phenomenon, a beloved, eccentric radio programme that has no counterpart elsewhere. This sentiment is evident in the travel writing inspired by the shipping forecast which never refers to the similarly iconic status of the shipping forecast in other countries. Nilsson and Nylund's Sjörapporten, a book that visits the remote places mentioned in the Swedish shipping forecast, excludes the ten stations located beyond the Swedish borders, one station in Norway, four in Denmark, one in Germany and four in Finland. They are apparently deemed irrelevant or uninteresting to the Swedish readership of the book, for they do not belong to "our shores" ("våra kuster") as defined in the subtitle of Nilsson and Nylund's book. ("Our shores" is a recurring phrase in the context of the shipping forecast: it also features in the subtitle of Peter Jeffersson's book, And Now the Shipping Forecast: A Tide of History around Our Shores, from 2011.) A significant exclusion in the book Sjörapporten is Märket, a small island of 300 square metres, the sole island space that has been divided between Sweden and Finland. The weather station is located on the only building on the island, the Märket lighthouse complex, which happens to stand just a few metres beyond the Swedish border - hence its exclusion from the domesticated version of sjörapporten.

While the original purpose of the broadcast was to ensure the safe passage of vessels, many of them bound to distant foreign ports, its cultural reception and especially the travel writing it has inspired reveals an opposing tendency of patrolling the borders, of separating the home waters and domestic culture from whatever lies, not necessarily beyond, but sometimes even within, the scope of the forecast.

\section{Nature}

Considering that the shipping forecast concerns a natural phenomenon weather - its reception and representation in fiction and poetry are oddly centred on the inner lives of human subjects. As so often in literature, nature is reduced to a mirror: it becomes a tool used to reflect on the mental stages and experiences of subjects, and thus it loses its fundamental materiality. The ability to reconnect humans to nature understood as the material world, and to encourage us to take responsibility for climatic changes, is perhaps an aspect of a yet undeveloped potential of the literary uses of the shipping forecast.

That potential is hinted at in Sari Vuoristo's collection of stories Säätiedotus merenkulkijoille (2008, "And Now the Shipping Forecast"). At the beginning of 
a story called "Silta" ("The Bridge"), a man is standing on a bridge in a rising storm, trying to face the fears that have haunted him ever since his childhood. Having fallen through the ice as a schoolboy, he has developed a fear of water that takes on existential proportions and haunts his married life. Facing the gushing wind, he ponders on the recent increase in the number and force of storms, and remembers how, a couple of years earlier, the water levels rose in the centre of Helsinki, and people poured into the city centre in order to wade on the market square and take photos, as if the flood were a spectacle for their amusement. Vuoristo plays down the ecological component of extreme weather conditions, however, by juxtaposing the flood in Helsinki with the 2004 Asian tsunami, a natural catastrophe not caused by man, and by turning the reader's attention to the protagonist's struggle against his own demons. Thus, the story perhaps unwittingly illustrates our inability to recognize and try to prevent significant changes in the environment.

A more complex approach to weather phenomena and the responsibility of humans is to be found in Tuuliatlas ("Wind Atlas", 2014), a collection of experimental poetry by the Finnish poet Mikael Brygger. The poetic diptych that opens the collection does not cite the shipping forecast, but builds on a similar meteorological discourse, though not one as culturally charged (or readily recognisable): the Beaufort scale of wind speeds. Copied almost verbatim from the "land and sea conditions" columns of the official scale, the poems combine one of the oldest functions of literature, the description or imitation of nature, with the contemporary aesthetics of found poetry ${ }^{7}$ that alerts us to the poetic qualities of non-literary texts. Progressing from a state of absolute calm to hurricane winds and raging waves, the poems describe, in the borrowed, exact language, the force of a natural phenomenon that overpowers the observing human: "näköpiirissä olevat laivat katoavat aaltovuoren taakse/koko merenpinta valkoisena; näkyryys erittäin huono" ["ships within eyeshot disappear behind a wall of waves/sea is completely white with foam and spray; very poor visibility"] (Brygger, 2014, n. p.). The flat, reporting tone of meteorological discourse is also evident elsewhere in the collection where individual poems repeatedly feature the imagery of wind, sea and storm. This imagery is mixed with other discourses, most prominently the currently omnipresent discourse of economy, which sees nature only as a potential resource: "yrityksemme nimi on Maapallo - /yrityssaneeraushakemus/poistuu aurinkokunnasta/vuonna 2048" ["our company is called the Earth/our application for reorganisation/will exit

7 Found poetry takes existing texts (newspaper articles, street signs, graffiti, speeches, letters, etc.) and refashions them to present them as poems. It is a form of literary collage (online). 
the solar system/in 2048"] (Brygger, 2014, n.p.). ${ }^{8}$ The poem prophesies the end of the world in the alienating and inconsequential vocabulary of business administration.

In their different ways, Brygger's and Vuoristo's texts undercut the comforting language of marine weather with a subtle sense of our inability to grasp the extent and severity of climate change. The shipping forecast, originally meant to protect individual vessels out at sea, has the potential to be transformed into a warning of a global storm that threatens the precarious balance of the ecosystem as we now experience it.

\section{Conclusion}

Literature of the shipping forecast is today a distinct literary phenomenon, with conventions of its own that are not restricted culturally or on the basis of language, regardless of the national emphasis in the original programme and its reception. My examples from Finnish, Finland-Swedish, Swedish, British and Irish literature demonstrate the continuing cultural significance of this peculiar radio format. Its applicability to so many different literary uses relies on its ability to cut across a number of seeming opposites, such as nature/culture, presence/distance, time/timelessness, oral/written, personal memories/collective experience, change/stability, centre/margins. The capacity of the shipping forecast to transport us to another place, be it an imaginary landscape or the familiar setting of our childhood, makes it a particularly apt discourse for exploring existential themes of longing and belonging in terms of navigation. Yet, it also lends itself to a critical examination of such escapes in a world of cultural and territorial conflicts and environmental instability.

\section{References}

Brannigan, John (2010). Dreaming of the Islands: The Poetry of the Shipping Forecast. UCD Scholarcast [online]. Available at: http://www.ucd.ie/scholarcast/transcripts/ shipping_forecast.pdf (Accessed: 04/o2/2019).

Brygger, Mikael (2014). Tuuliatlas. Helsinki: Osuuskunta Poesia.

Carolan, Victoria (2011). The Shipping Forecast and British National Identity. Journal for Maritime Research, 13(2), pp. 104-116.

8 Translation is by the author. 
Compton, Nic (2016). The Shipping Forecast. London: BвC Books.

Connelly, Charlie (2004). Attention All Shipping: A Journey Round the Shipping Forecast. London: Little, Brown.

Dahlberg, Julia (2011). Islossning. Helsingfors: Söderströms.

Duffy, Carol Ann (1993). Mean Time. London: Anvil.

Found Poetry: Poetic Form (2004). [online]. Available at https://www.poets.org/poetsorg/text/found-poem-poetic-form (Accessed: 11/02/2019).

Hakkarainen, Anna-Kaari (2014). Purkaus. Helsinki: Tammi.

Heaney, Seamus (1998). Opened Ground: Selected Poetry 1966-1996. New York: Farrar, Strauss \& Giroux.

Jefferson, Peter (2011). And Now the Shipping Forecast: A Tide of History around Our Shores. Cambridge: UiT Cambridge.

Körling, Anne-Maria (2014). Att lyssna till sagan om dagens land - och sjöväder. Körlingsord, October 3 [online]. Available at: http://korlingsord.se/archives/40046 (Accessed: 04/02/2019).

Maijala, Marika, and Virta, Juha (2010). Sylvi Kepposen hukkaretki. Helsinki: Otava.

Met Office - Shipping Forecast. [online]. Available at: https://www.metoffice.gov.uk/ public/weather/marine/shipping-forecast (Accessed: 04/o2/2019).

Nilsson, L.-G., and Nylund, Anders (2012). Sjörapporten: Om väder, fyrar och skeppsbrott längs våra kuster. Stockholm: Nordstedts.

Schalansky, Judith (2010). Atlas of Remote Islands: Fifty Islands I Have Not Visited and Never Will. Translated by C. Lo. London: Particular Books/Penguin.

Street, Seán (1999). Radio and Other Poems. Ware: Rockingham Press.

Tamminen, Petri (2002). Piiloutujan maa. Helsinki: Otava.

Tamminen, Petri (2007). Hiding Places. Translated by O. Wilson. Beaverton, ON: Aspasia Books.

Wallen, Anne B. (2014). Mapping the Personal in Contemporary German Literature. In: R.T. Tally Jr., ed., Literary Cartographies: Spatiality, Representation, and Narrative, Geocriticism and Spatial Literary Studies, New York: Palgrave Macmillan, pp. 181-198. Waterman, Andrew (2000). Collected Poems 1959-1999. Manchester: Carcanet.

Young, Kevin (2007). The Shipping Forecast's “Baffling” Legacy. BBC News 27.09.2007 [online]. Available at: http://news.bbc.co.uk/2/hi/entertainment/6940597.stm (Accessed: 04/02/2019). 